\title{
Workload, capacity for coping and psychological and physical outcomes amongst home helps in the Netherlands
}

\author{
S. E. J. Arts ${ }^{1}$ MSc, A. Kerkstra ${ }^{1} \mathrm{PhD}$, J. van der Zee ${ }^{1} \mathrm{PhD}^{*}$ and H. Huyer Abu-Saad ${ }^{2} \mathrm{PhD}, \mathrm{RN}$ \\ ${ }^{1}$ NIVEL (Netherlands Institute of Primary Health Care) ${ }^{2}$ University of Maastricht, Faculty of Health Sciences, Department \\ of Nursing Science
}

\author{
Correspondence \\ Mrs S. E. J. Arts \\ NIVEL \\ PO Box 15683500 \\ BN Utrecht \\ The Netherlands
}

\begin{abstract}
Owing to many developments and changes in home care in the Netherlands, a national study was carried out. One of the aims was to examine the differences between the six categories of home help in the Netherlands regarding workload, pressure of work and capacity for coping. A total of 474 home helps from six categories participated in the study. A structured questionnaire, based on the components of the research model, was used, which consisted of existing scales regarding workload (organizational and job characteristics, working conditions), psychological and physical outcomes (job satisfaction, burnout, health) and capacity for coping (social support, leadership style, coping strategies). Workload, specifically organizational and job characteristics are scored low by alpha helps and, to a lesser degree, by A home helps. The higher categories of home help experienced relatively bad working conditions. Home helps, except for alpha helps, are, on the whole, quite satisfied with their work, which is one of the psychological and physical outcomes. The higher categories of home help (C, D and E carers) experienced high feelings of emotional exhaustion. Health, absenteeism and back problems did not differ significantly amongst home helps. When looking at capacity for coping, traditional home helps (A to E) received more social support. The subordinate categories of home help dealt less actively with their problems and sought less social support than the other categories. Alpha helps are not employed by the organization and this might cause low organizational and job characteristics, and little social support. Their satisfaction scores suggest that they would like to see their low organizational involvement changed. The higher categories of home help, who carry out many psychosocial tasks, have higher emotional and mental workload and high burnout scores. B, C and D carers, who perform personal care and have to adhere to strict planning, experience extreme time pressure and a high physical workload.
\end{abstract}

Keywords: capacity for coping, home help services, psychological and physical outcomes, the Netherlands, workload

\section{Accepted for publication 27 April 1998}

\section{Introduction}

In the last decade, home care organizations in the Netherlands have been confronted with some serious problems, as was shown in a previous paper on home help in the Netherlands (Arts et al. 1998). Besides a higher and more complex demand for home care and the existence of waiting lists, home care organizations have been confronted with two other problems.

The first problem is a shortage of personnel, which will become even more serious in the near future: a shortage of 7500 home helps ( $7 \%$ of present number of home helps) in the Netherlands is expected in the year 
2000 (van Tits \& Groot 1991, van Tits \& Vermeulen 1992). A shortage of personnel is also a problem in many countries in Europe, including Austria, Denmark, France, Greece, Ireland, Italy, Luxembourg and Portugal. The reasons for this shortage are that the profession is not considered attractive, because it has low status, is poorly paid and the training is considered to be inadequate (Hutten \& Kerkstra 1996).

The second problem is that absenteeism due to illness amongst these health care workers is very high: 9.5\% in 1995 (BVG 1996). Amongst the main reasons for absenteeism in home help services are problems of the musculo-skeletal system (back problems) (43\%), followed by psychological problems (30\%) (Veerman 1989). When these problems become chronic, the afflicted individual has a good chance of receiving disablement insurance benefits (WAO). In 1993, 2.9\% of the employees in Dutch home help services were getting disablement insurance benefits. Amongst all Dutch health care workers, the average percentage is only 1.6\% (BVG 1994). In the Netherlands, turnover is also very high in home help services. In 1993, 28\% of the employees left the sector (Hornman 1994). An overview of the organization and provision of home help services is provided by Arts et al. (1998).

Differentiated practice, that is a clear distinction in the work between the various categories of home help, was expected to have a positive influence on the regulation of these problems. In 1993, new job designations for home helps were introduced with the new Collective Labour Agreement. Since then, six categories of home help have been distinguished: alpha helps ${ }^{\mathrm{X}}$, A home help, B caring help, C carer, D carer, and specialized E carer. Each category has its own task profile, as is shown in Table 1 (Union for Public Sector Workers: AbvaKabo 1994). The Table shows that alpha helps only carry out housework; A home helps are restricted to housework; B caring helps do the housework and give some personal care; $\mathrm{C}$ carers are mainly involved in providing personal care and some house- hold work; D carers mostly carry out personal care and psychosocial or supportive tasks; and specialized E carers support households with multiple complex problems.

It is hoped that the system of differentiated practice will provide home helps with more promotion and development opportunities, and thus more career opportunities. This is required to change a rather unattractive profession as home help with limited prospects into a more attractive one, and hopefully at the same time reduce the high percentages of absenteeism in home help services. This study will show what other changes have to be made to achieve this.

This paper is the second of a series of two on home help services in the Netherlands. In the first paper, the job content of the various categories of Dutch home help was described and compared with formal job descriptions (Arts et al. 1998). Based on the use of time spent by home helps and the activities they carried out, we concluded that housework is mainly done by the three subordinate categories of home help (alpha helps, A home helps, B caring helps). Personal care is performed by $\mathrm{C}$ and $\mathrm{D}$ carers and by $\mathrm{B}$ caring helps, and psychosocial activities are done by all categories of home help, but mostly by specialized E carers. Reporting is also done by all home helps, except alpha helps. The second conclusion was that housework or personal care are not carried out alone, but in combination with other activities. And the third conclusion was that the actual practice in home help services does not correspond with the above-mentioned formal task profiles. In daily practice, the four subordinate categories of home help carry out more psychosocial activities. Additionally, A home helps, B caring helps and C carers do more in the area of consultation and co-operation (reporting) than is in their formal job description. A further, fourth conclusion was that certain home helps carry out more activities than they are supposed to in their daily practice: $\mathrm{C}, \mathrm{D}$ and $\mathrm{E}$ home helps carry out more housework, and alpha helps, A, B and C

Table 1 Formal task profile for each category of home help

\begin{tabular}{lllll}
\hline & Activities & & \\
\cline { 2 - 5 } Categories of home help & Housework & Caring & $\begin{array}{l}\text { Psychosocial/ } \\
\text { supportive }\end{array}$ & $\begin{array}{l}\text { Cooperation and } \\
\text { consultation }\end{array}$ \\
\hline Alpha help & $X$ & & & \\
A home help & $X$ & & & - \\
B caring help & $X$ & - & $X$ & $X$ \\
C carer & - & $X$ & $X$ & \\
D carer & - & - & & \\
Specialized E carer & - & X & & \\
\hline
\end{tabular}

$\mathrm{X}=$ main tasks; - = secondary tasks. Source: AbvaKabo 1994. 
home helps carried out more psychosocial/supportive activities. Unfortunately, during assessment no extra time was reserved for the majority of the psychosocial activities. Finally, a major overlap was found in the content of the work of the consecutive home helps (A and B home helps, and C and D carers). A new differentiation, with only four categories of home help, was suggested (Arts et al. 1998).

This paper, the effect of this division of tasks on the pressure of work of Netherlands home helps is reported. Pressure of work is defined as the subjective experience of workload and is operationalized to include job satisfaction, burnout and health or absenteeism. A research model was developed to measure this (Arts et al. 1997). The model is based on various models and theories on quality of working life in combination with the workload/capacity-model (Hackman \& Oldham 1974, 1975, 1976, 1980, Karasek 1979, Meijman \& O'Hanlon 1984, Veerman 1989, Karasek \& Theorell 1990, Smulders \& Veerman 1990). The workload or capacity-model is used as a stepping-stone to integrate the theories and models on quality of working life. This research model has three dimensions: workload, psychological and physical outcomes and capacity for coping.

The main research question in this paper is: What are the differences between the six categories of home help regarding workload, psychological and physical outcomes and capacity for coping?

On the basis of earlier work (Arts et al. 1998) some expectations for this study were formulated:

- it was expected that alpha help would score low on organizational characteristics and on some job characteristics, because they are not employed by the organization and therefore have no strong relation with the organization, colleagues and intermediaries, consequently receive no feedback, and are not entitled to receive education.

- home helps were expected to be exposed to time pressure, because they have to carry out extra activities for which, during assessment, no extra time was planned. The time pressure is expected to be higher for home helps who visit more than two or three clients on a day, with many personal care.

- home helps were expected to have a high emotional and mental workload owing to the extra psychosocial activities they carry out. For the higher categories of home helps (C, D and E carers), who carry out more complex work, this might even be higher. This also implies that these higher categories of home help also score higher on the burnout scales.
- with regard to the various activities home helps undertake, the subordinate categories are expected to view their work as more monotonous than the higher categories of home help.

- the higher categories of home help spend more time on meetings and other activities, and are therefore expected to receive more information about their work (feedback).

\section{Methods}

\section{Sample}

A two-stage sampling method was used to obtain a representative sample of home helps. For the organizations, three stratification criteria were used: region (the four regions north, south, east and west), integration process of the home help organization (integrated with home nursing or not), and catchment area of the organization (care provided in an area including a city of more than 100000 thousand inhabitants or not). This resulted in a matrix of 16 cells, containing all the 104 organizations for home help services in the Netherlands. From each cell, one organization was randomly selected and asked to participate in the study. If an organization did not want to participate, another organization from the same cell was asked. In total 30 organizations were asked to participate.

Each organization was asked to recruit 30 home helps, equally divided over the six categories of home helps. There was one inclusion criterion for home helps: they had to have been in service for at least 1 month. A total of 510 home helps (one organization participated with two teams), was expected to take part in the study.

\section{Procedure}

During an information meeting, the purpose of the study was explained to the participating home helps, and all forms that were to be used during the registration period, were explained fully. Following this instruction, the home helps were asked to fill in the questionnaire on pressure of work.

\section{Instrument}

Questionnaire on pressure of work

In order to examine possible constraining aspects of home helps, a structured questionnaire was used, based on the research model 'Pressure of work in home help services' (Arts et al. 1997). The questionnaire on pressure of work consisted of existing scales for the components of the model: workload, psychological 
and physical outcomes and capacity for coping. The scales were validated in previous studies, with Crombach's alpha's varying between 0.60 and 0.90 (Bergers et al. 1986, Boumans 1990, van Veldhoven \& Meijman 1994; Schaufeli \& van Dierendonck 1994).

Workload, the activities that someone has to carry out in a particular environment, can be classified using three types of variable: organizational characteristics (Veerman 1989, Engelen 1993); job characteristics (Hackman \& Oldham 1974, 1975, 1976, 1980); and working conditions (Karasek 1979, Karasek \& Theorell 1990).

The questionnaire 'Experience and Assessment of Work' (VBBA) by van Veldhoven \& Meijman (1994) was used for scales on organizational characteristics, job characteristics and working conditions. The organizational characteristics were operationalized into three subscales: communication with organization $(\alpha=0.69)$, contact opportunities with colleagues $(\alpha=0.68)$ and substitution during illness. Four job characteristics were measured: skill variety $(\alpha=0.71)$; feedback ( $\alpha=0.76)$; autonomy ( $\alpha=0.81)$; and learning and growth opportunities $(\alpha=0.81)$. Finally, working conditions were operationalized into seven subscales: role ambiguity, clarity concerning a specific task or concerning the expectations of a client regarding a specific task $(\alpha=0.61)$; role conflict, performing tasks that are conflicting or performing tasks one prefers not doing $(\alpha=0.61)$; time pressure $(\alpha=0.88)$; physical, emotional and mental workload ( $\alpha=0.82, \alpha=0.76$, $\alpha=0.88$, respectively) and safety at work.

Psychological and physical outcomes is defined as the subjective experience of the actual workload. Pressure of work is operationalized in this model to include job satisfaction, work performance and work motivation (Hackman \& Oldham 1974, 1975, 1976, 1980), burnout and health or absenteeism (Karasek 1979, Veerman 1989, Karasek \& Theorell 1990).

Based on the study by Boumans (1990), job satisfaction was measured by nine subscales: satisfaction with clarity at work $(\alpha=0.71)$; satisfaction with growth at work $(\alpha=0.75)$; satisfaction with promotion opportunities $(\alpha=0.82)$; satisfaction with contact with colleagues $(\alpha=0.95)$; satisfaction with contact with supervisor $(\alpha=0.87)$; satisfaction with contact with clients ( $\alpha=0.76)$; work performance $(\alpha=0.78)$; internal work motivation $(\alpha=0.43)$; and general work fulfilment $(\alpha=0.78)$. The Dutch translation of the Maslach Burnout Inventory (MBI-NL) by Schaufeli \& Van Dierendonck (1994) was used to measure burnout. Burnout is operationalized into questions regarding emotional exhaustion $(\alpha=0.86)$; depersonalization $(\alpha=0.52)$; and personal accomplishment $(\alpha=0.72)$. Health was estimated by a self-assessment of the general health state on a five-point scale from very bad to very good.

Capacity for coping is the third component of the model. It is hypothesized that pressure of work is also affected by the mental capacity (personal circumstances, recognition from others, social position of profession) of the home help and the support experienced by the home help. Social support includes the leadership style and support from supervisors, colleagues, partner, clients and other care-givers (Hackman \& Oldham 1974, 1975, 1980, Karasek 1979, Veerman 1989, Boumans 1990, Karasek \& Theorell 1990, Hood \& Smith 1994). Personal characteristics in this model are coping strategies (Hackman \& Oldham 1974, 1975, 1980, Veerman 1989), biographical characteristics (Hackman \& Oldham 1974, 1975, 1980, Karasek 1979, Veerman 1989, Boumans 1990, Karasek \& Theorell 1990) and category of home help (Jansen et al. 1996).

Social support experienced at work was measured by questions regarding experienced social support from supervisors $(\alpha=0.72)$, colleagues $(\alpha=0.83)$ and partners $(\alpha=0.80)$ from the Organizational Stress Questionnaire (VOS-D) (Bergers et al. 1986). The leadership style scales were constructed by Boumans (1990), based on the Algera questionnaire (Algera 1981, Algera et al. 1986). Two types of leadership are measured: social-emotional leadership $(\alpha=0.96)$ and instrumental leadership ( $\alpha=0.91)$. To assess ways of dealing with problems, a shortened version by Dierendonck et al. (1992) of the Utrecht Coping List (UCL) by Scheurs et al. (1988) was used. Coping strategies were measured on this 25 item questionnaire by three subscales: active approach $(\alpha=0.77)$, passive approach $(\alpha=0.76)$ and seeking social support $(\alpha=0.79)$.

As described above, the reliability of these scales was calculated for this group of home helps $(n=474)$, and the majority of the reliability scores were sufficient (higher than $\alpha=0.60$ ), varying between 0.61 and 0.96 . The reliability of two subscales was insufficient: internal work motivation (job satisfaction) $(\alpha=0.43)$ and depersonalization (burnout) $(\alpha=0.52)$. Therefore, for this study, the subscales of burnout and job satisfaction were removed from analysis. Although the reliability of the depersonalization-scale in other burnout-studies (van Dierendonck et al. 1992; Jansen et al. 1996, van Dierendonck 1997) is also the lowest of the three dimensions, in those studies the scores were still acceptable (respectively $\alpha=0.64, \alpha=0.64, \alpha=0.71$ [Table 2]).

\section{Analysis}

Analysis of variance (one-way) was used to test for significant differences between the mean scores of the 
Table 2 Reliability scores of the scales used in the questionnaire 'Pressure on work', with accompanying Crombach's alpha's and the number of items per scale $(n=474)$

\begin{tabular}{|c|c|c|}
\hline Crombach's & $\alpha$ & item \\
\hline \multicolumn{3}{|l|}{ Organization characteristics } \\
\hline Communication w. Organization & 0.69 & 4 \\
\hline Contact with colleagues & 0.68 & 4 \\
\hline \multicolumn{3}{|l|}{ Job characteristics } \\
\hline Skill variety & 0.71 & 6 \\
\hline Feedback & 0.76 & 6 \\
\hline Autonomy & 0.81 & 11 \\
\hline Learning-and growth opportunities & 0.81 & 9 \\
\hline \multicolumn{3}{|l|}{ Working conditions } \\
\hline Role ambiguity & 0.61 & 5 \\
\hline Role conflict & 0.61 & 6 \\
\hline Physical workload & 0.82 & 7 \\
\hline Mental workload & 0.88 & 7 \\
\hline Emotional workload & 0.76 & 7 \\
\hline Time pressure & 0.76 & 11 \\
\hline \multicolumn{3}{|l|}{ Burnout } \\
\hline Emotional exhaustion & 0.86 & 9 \\
\hline Depersonalization & 0.52 & 5 \\
\hline Personal accomplishment & 0.72 & 8 \\
\hline \multicolumn{3}{|l|}{ Job satisfaction } \\
\hline Clarity & 0.71 & 5 \\
\hline Colleagues & 0.95 & 6 \\
\hline Supervisor & 0.87 & 6 \\
\hline Growth & 0.75 & 3 \\
\hline Promotion & 0.82 & 4 \\
\hline Clients & 0.76 & 4 \\
\hline Work performance & 0.78 & 7 \\
\hline General work fulfilment & 0.78 & 7 \\
\hline Work motivation & 0.43 & 4 \\
\hline Total satisfaction & 0.95 & 42 \\
\hline \multicolumn{3}{|l|}{ Experienced social support } \\
\hline Supervisors & 0.72 & 5 \\
\hline Colleagues & 0.83 & 5 \\
\hline Partner & 0.80 & 5 \\
\hline \multicolumn{3}{|l|}{ Leadership style } \\
\hline Socio-emotional & 0.96 & 11 \\
\hline Instrumental & 0.91 & 9 \\
\hline \multicolumn{3}{|l|}{ Coping-strategies } \\
\hline Active approach & 0.77 & 7 \\
\hline Passive approach & 0.76 & 12 \\
\hline Seeking social support & 0.79 & 6 \\
\hline
\end{tabular}

six categories of home help on the various scales of the questionnaire on pressure of work. The Bonferroni test (a modified least significant difference test), was used to determine which means were significantly different from each other (Norusis et al. 1992).

\section{Results}

\section{Response}

Thirty organizations for home help or home care were asked to participate in the study. Fourteen organizations declined to take part. The main reasons for not participating were lack of time due to reorganization or merger (6) or involvement in other research (8). Finally, 16 organizations (53\%) took part in the study.

Each organization was expected to select 30 home helps, five from each of the six categories of home help (510 home helps). Not all organizations were able to select these 30 home helps, because there were not always five home helps in each category, nor were all six categories of home help present or available in all organizations. Finally, 474 home helps (93\%) were selected to participate in the study. The way the home helps were selected for the study, either voluntarily or selected by a supervisor, could bias the results. Both the total number of home helps participating from 16 organizations and the number of home helps per category were sufficient for a representative picture of the work of home helps in the Netherlands and for an accurate comparison between the six categories of home help, respectively.

All 474 home helps filled in the questionnaire. Table 3 shows the distribution of the number of home helps over the six categories of home help.

Almost all of the $(97 \%)$ of home helps were women. The mean age of the home helps was 39 years with a standard deviation of 10 , and the average hours worked per week were $20(\mathrm{sd}=10)$.

\section{Missing data}

Scales were constructed based on the sum of the relevant items. When half or fewer of the items were missing, the scale was constructed based on the valid items. Alpha helps were not able to fill in certain scales regarding contact with colleagues, social support from colleagues and from other care-givers, and regarding leadership styles, because of their working situation. Alpha helps are not employed by the organization but by their client(s). Accordingly they have no direct supervisor and no opportunities to meet other alpha helps. Consequently, certain scores of alpha helps are missing in Tables 4 and 6.

Table 3 Distribution of home helps over the six categories of home help

\begin{tabular}{lr}
\hline Alpha-helps & 73 \\
A home helps & 90 \\
B caring helps & 94 \\
C carers & 84 \\
D carers & 78 \\
Specialized E home carers & 55 \\
Total & 474
\end{tabular}



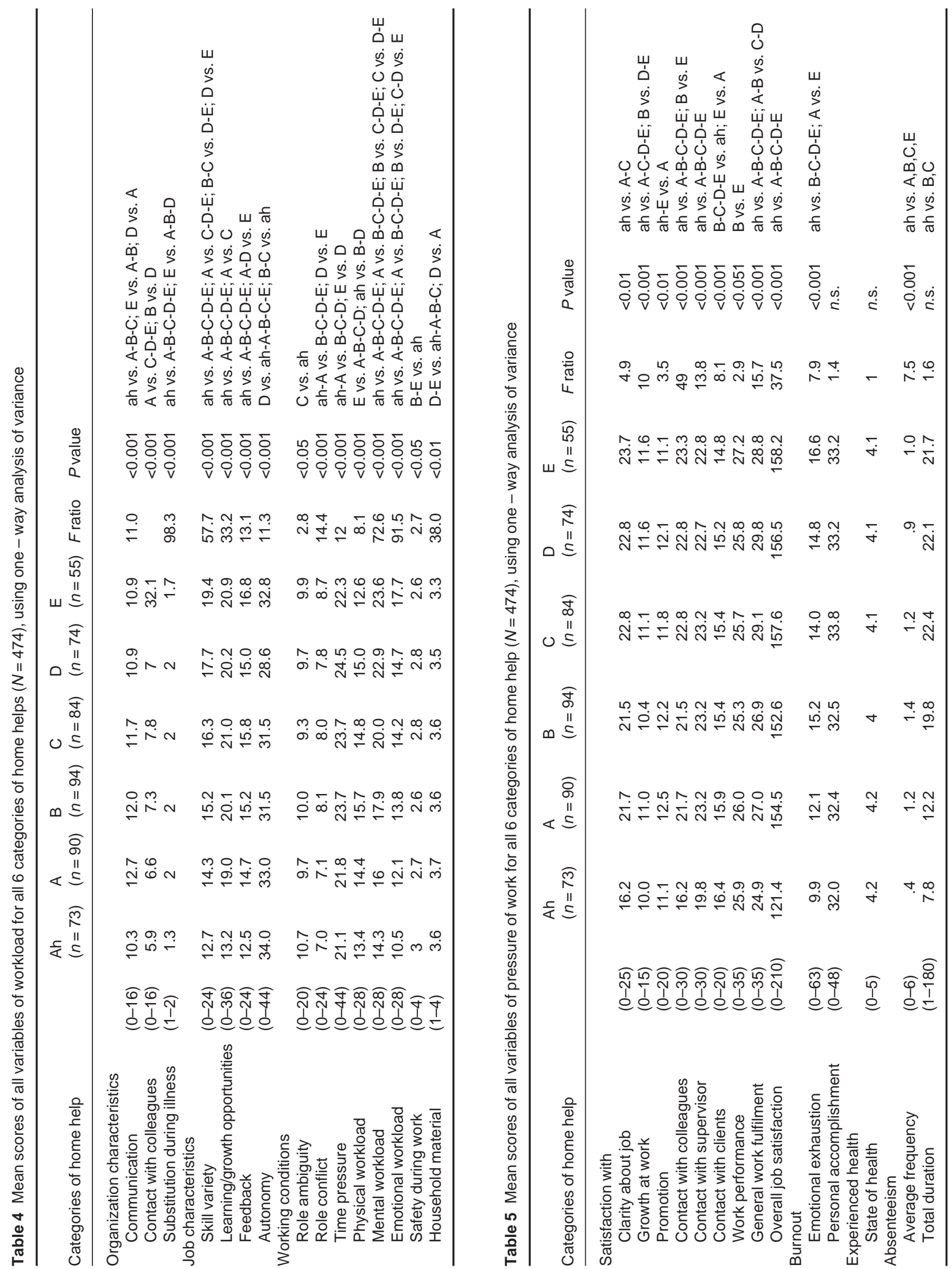


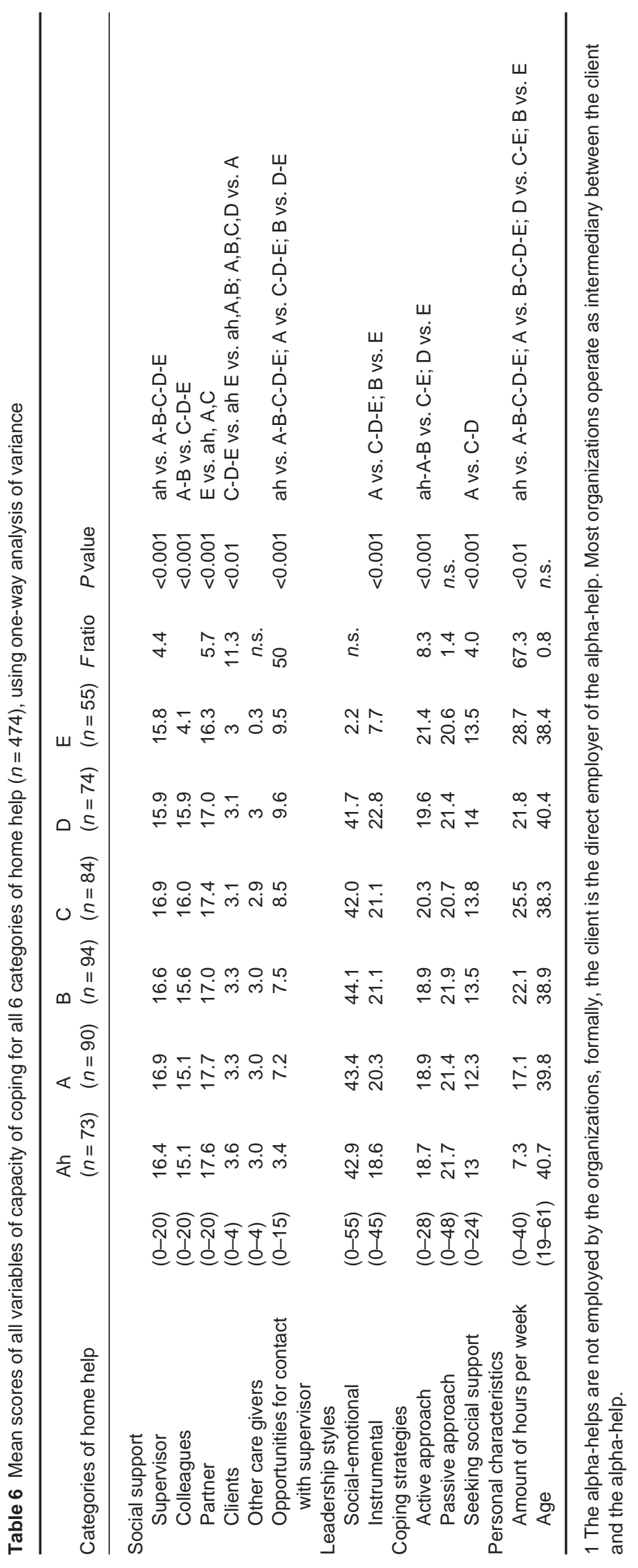


The mean scores of the six categories of home help on all variables of the questionnaire are presented in Tables 4,5 and 6 . High scores indicate a high presence of the variable. For example, specialized E carers had significantly more skill variety in their work than the other categories of home help (Table 4).

\section{Workload}

Table 4 shows that opportunities for contact with colleagues, and for communication with the organization, two organization characteristics, were different for the various categories of home help. Alpha helps scored low on these scales. The other home helps generally found few opportunities for contact. Substitution during illness was also examined. For alpha helps and specialized E carers this was insufficiently organized.

Job characteristics such as a high degree of skill, variety, learning and growth opportunities increased for higher categories of home help. Alpha helps and A home helps experienced the lowest skill variety, learning and growth opportunities and feedback. On the other hand alpha helps have a much higher degree of autonomy than $\mathrm{B}$ caring helps, and $\mathrm{C}$ and $\mathrm{D}$ carers.

Seven types of working conditions were measured in the questionnaire, varying for all categories of home help. Alpha helps felt safest in their work, experienced the highest role ambiguity (lack of clarity about a specific task or about the client's expectations of a home help), and the lowest role conflict (performing conflicting tasks). Both B caring helps and $C$ and $D$ carers scored very high on the physical working conditions like time pressure and physical workload. The other two types of workload, mental and emotional, increased for higher categories of home help: the lowest degree of mental and emotional workload was experienced by alpha helps and the highest of both by specialized E carers. Both D carers and specialized E carers rated the quality of the household material as lowest.

\section{Psychological and physical outcomes}

Job satisfaction on seven work elements was assessed. Table 5 shows that alpha helps were considerably less satisfied with almost all work aspects than were other home helps, except for contact with clients. A home helps were most satisfied with clarity in their task, with promotion opportunities, contact with supervisor, and also scored high on contact with clients. Specialized E carers were also quite satisfied with growth at work, contact with colleagues, and work performance. D carers had the highest general work fulfilment. Alpha helps also experienced the lowest overall job satisfaction, which was estimated taking into account the various parts of job satisfaction.

In this study, burnout is operationalized in questions regarding emotional exhaustion and personal accomplishment. Alpha helps were significantly less emotionally exhausted compared with the four highest categories of home help. Personal accomplishment was not scored significantly differently amongst the six categories of home help.

The home helps also made an assessment of their health. In general, all home helps felt quite healthy, and this state of health did not differ between the home helps. There were significant differences in the frequency of absenteeism between the home helps. Alpha helps were least often absent due to illness compared with the other categories of home help, except D carers. There were no significant differences in the average period of illness between the home helps.

The prevalence of back problems amongst home helps is relatively low: one-third of the home helps had back problems during the previous 12 months. Back problems occurred with equal frequency amongst the six categories of home help (not included in the tables).

\section{Capacity for coping}

Social support in their work from supervisors, colleagues, partners, clients and other care-givers was also measured. Table 6 shows that alpha helps scored significantly lower on social support from supervisors compared with all other categories, although they scored highest on social support from their clients. Specialized E carers experienced the lowest level of support from their clients, just as they experienced the lowest level of satisfaction with their clients (Table 5). Compared with alpha helps, $C$ carers received most social support from supervisors, and the higher categories of home help received significantly more social support from their colleagues than alpha helps, A home helps and B caring helps. All categories of home helps felt, in general, well supported by their partners. Support from other care-givers increased with higher categories of home help (B caring helps, C and D and specialized E carers).

All home helps said their supervisor more often used a social-emotional leadership style (focused on well-being and comfort) than an instrumental leadership style (mainly focused on production). A home helps experienced the lowest instrumental leadership style and specialized E carers experienced the highest.

There are three ways of dealing with problems and events (coping strategies); actively, passively and seeking social support. C carers and specialized E carers used the active approach significantly more. The 
scores on the passive coping strategy were not different amongst the six categories of home help. Seeking social support is a coping strategy less used by A home helps.

\section{Conclusion}

\section{Workload}

As expected, alpha helps score low on organizational and job characteristics in their work due to the fact that they are not employed by the organization. The results of another Dutch study on home helps by van den Herik et al. (1995) confirm these findings. Because alpha helps work more independently, they experience more autonomy. These feelings decrease amongst the higher categories of home help (B, C and D home helps).

Home helps who predominantly do housework (alpha helps and A home helps) experience less variety in their work. This is in line with Veerman's (1989)conclusion that home helps describe housework as 'little variety between strenuous and less strenuous work'.

It was also expected that the higher categories of home help would receive more feedback, because they were more involved in meetings and therefore have more information about their work. This turned out to be partly true: only specialized E carers scored significantly higher on this compared with alpha helps, A home helps, and D carers.

As expected, results showed that higher categories of home help, who carried out more personal and psychosocial care, and thus more complex work, have a higher mental and emotional workload than alpha helps and A home helps. The subordinate categories of home help probably have a smaller chance of mental or emotional overload, because they work fewer hours per week. Interestingly, home helps have a lower mental workload (19.1 versus 22.6) and a higher emotional workload (13.8 versus 11.2) compared with other groups of women health care workers (van Veldhoven \& Meijman 1994).

Higher categories of home help also had more role conflict. This corresponds with Veerman's (1989) where he found a relationship between higher categories of home help, role conflict and psycho-social workload.

Home helps were expected to be exposed to time pressure, especially the higher categories of home help, because of the nature of their activities and the extra activities they had to carry out and our results confirm this expectation. Compared with another group of women health care workers, home helps experienced a greater time pressure (22.9 versus 11.6; van Veldhoven \& Meijman 1994). B, C and D carers experienced a greater time pressure and a higher physical workload than the other home helps. The type of work is probably the underlying reason: they all give personal care in many different client situations each day, with a fixed time frame. Veerman (1989) concluded that working at several addresses each day causes a high workload for home helps (Veerman 1989).

\section{Psychological and physical outcomes}

Home helps were, in general, reasonably satisfied with their work, as were the home helps in the study by van den Herik's et al. (1995). Alpha helps however, were significantly less satisfied with their work, especially with task clarity, growth and promotion opportunities at work and with opportunities for contact with supervisors and colleagues. Alpha helps scored low on the presence of these items, except for role ambiguity and the low satisfaction scores indicate that they would like to see this changed. They would like to have more contact with their organization (supervisors and colleagues) than they have now, receive some training, experience less ambiguity in their work. Alpha helps also score very low on the overall job satisfaction. In order to get a better understanding of these scores, an average overall job satisfaction score was calculated for all home helps (3.55) and compared with an average overall job satisfaction score for community nurses (3.67; Jansen et al. 1996). The averages are similar, and both home helps and community nurses are therefore reasonably satisfied with the various aspects of job satisfaction.

Alpha helps have no rights under Dutch Health Law for example, they do not receive sick pay. Accordingly, they will first try to reschedule appointments with the clients before they call in sick. This is a feasible explanation for the low level of absenteeism per year for alpha helps.

Back problems amongst home helps are an important problem. However, compared with other health care workers, the incidence rates are lower: one-third of the home helps experienced back problems in the previous 12 months compared with more than half (56\%) of nursing and caring staff in nursing homes (Bakker et al. 1995). This figure may be an underestimation, due to the selection procedure of home helps. It is likely that home helps with serious back problems were not asked to participate or could not participate in the study due to their state of health.

As was expected, feelings of emotional exhaustion are highest for the higher categories of home help. A feasible explanation for this is that the subordinate categories of home help (alpha helps, A home helps and B caring helps) work fewer hours per week and therefore run a smaller chance of emotional or physical overload. The averages of these scores were compared 
with average norm scores from a study by Schaufeli \& van Dierendonck (1994) of 2500 nurses. On a scale from 1 to 6 , the average score for emotional exhaustion is 1.9 and home helps score 1.5 (scores between 1.1 and 2.5 are average). The average score for personal accomplishment is 3.9 and home helps score 4.1 (scores between 3.4 and 4.3 are average; Schaufeli \& van Dierendonck 1994). Compared with the norm-scores, home helps had average scores on the two burnout dimensions.

\section{Capacity for coping}

As Veerman (1989) concluded, home helps experience in general high social support, with the exception of alpha helps. It was expected that alpha helps would experience less support from supervisors and colleagues, because they have hardly any contact with them. Nevertheless, they feel better supported or appreciated by their clients than the other home helps. This is logical as alpha helps are formally employed by the client and therefore have a different relationship with them from that of other home helps with their clients. This kind of support decreases with higher categories of home help, especially with the specialized $\mathrm{E}$ carer. The type of client and the nature of the help provided probably have an influence on the relationship between carer and client.

Higher categories of home help felt more supported by other care-givers, compared with the subordinates categories, probably because they, and especially specialized E carers, have more contact with other professionals and therefore may receive more support or appreciation from them.

Specialized E carers used an active approach significantly more compared than the other five categories. For a better idea of these scores, the average scores were compared with the average coping scores of Dutch community nurses (Jansen et al. 1996). On a scale from 1 to 4 , the average score for the active approach to the problems of home helps is 2.81 and for community nurses 2.95 . For the passive approach the average score of home helps is 1.77 and of community nurses 1.96 , these scores are similar. The average score on seeking social support is 2.22 for home helps and 2.65 for community nurses. This coping strategy was used less by home helps than by community nurses.

\section{Discussion}

This study was carried out to gain insight into the effect of division of tasks, differentiated practice, on the pressure of work of home helps in the Netherlands.
The system of differentiated practice was expected to provide home help with more prospects in their jobs, and to improve the attractiveness of the occupation. Consequently, the percentage of absenteeism in organizations for home help services was predicted to decrease.

The differences between the six categories of home help with regard to workload, pressure of work and capacity for coping were studied. Four profiles can be distinguished: alpha helps; home helps mainly involved in housework; home helps mainly involved in personal care; and home helps with complex work. These profiles are comparable with the new categorization of home helps, suggested by Arts et al. (1998).

Alpha helps score very low on organizational characteristics, experience lack of clarity concerning specific tasks or concerning the expectations of clients regarding specific tasks; receive only little social support from supervisors and colleagues, They were, in general, dissatisfied with many aspects of their work and specifically with opportunities for contact and for growth and promotion, and scored low on general work fulfilment. Alpha helps experienced high autonomy in, and safety during, work and high social support from their clients.

Home helps mainly involved in housework (alpha helps and A home helps) experienced little skill variety, feedback, learning and growth opportunities, but their working conditions were reasonably good; they scored low on role conflict, physical, mental and emotional workload. Home helps involved in housework experienced high social support from their clients and were satisfied with this and had low feelings of emotional exhaustion (burnout).

Carers, home helps involved in personal care (B, C and $\mathrm{D}$ carers), experienced high time pressure and high physical workload.

Home helps with complex work (personal care and psychosocial or supportive tasks), thus C, D and E carers, scored high on several organizational and job characteristics (contact with organization, supervisor and colleagues, skill variety, and feedback). They also experienced high social support from supervisors, colleagues and other professional care-givers, and used an active approach to deal with problems. These higher categories of home helps were quite satisfied with the contact with supervisors and colleagues, and opportunities for growth in their work. However, they had a high mental and emotional workload and experienced extreme feelings of emotional exhaustion (burnout). Finally, their supervisors have an instrumental leadership style, meaning that they define and clarify the role of the home help and tell them exactly 
what they are expected to do, rather than focusing on well-being and comfort.

\section{Recommendations}

Although differentiated practice has been implemented in Dutch home help services, the situation with regard to workload, psychological and physical outcomes and capacity for coping still should be further improved: decreasing the workload and pressure of work of home helps and increasing the home helps' capacity for coping. In order to make home help services more attractive to work in, improvements have to be made for all four profiles.

Although for alpha helps major improvements should be made in the area of social support, promotion and growth opportunities and various work aspects, their legal working situation - employed by the client and not by the organization - does not allow for these changes.

Home helps mainly involved in housework lack satisfactory job characteristics. For these home helps, new tasks have to be created to reduce the monotony of work, and supervisors have to pay more attention to this group of home helps (feedback). Further, the organization should provide them with more training and with more prospects in their job.

An improvement of working conditions is required for the carers. During the assessment-procedure, the allocation of time needs special attention to prevent time pressure amongst these home helps. Better material, aides and training on how to work ergonomically is needed.

Teaching home helps with complex work how to deal with stressful working situation, and thus how to decrease high emotional and mental workload and high feelings of emotional exhaustion, is highly recommended.

\section{Limitations of the study}

The study has some restrictions with regard to the sample of home helps participating.

The way the home helps were selected for the study, either volunteering or being selected by a supervisor, could bias the sample. Home helps who had long-term ill health were not included. Therefore, the results may appear a little clear cut, but they are in line with other studies on home helps (Veerman 1989, van den Herik et al. 1995, Commissie Verzorging 1995). A final restriction is the number of home helps from each category. Although this was required to adequately compare the scores between the six categories of home help, it is not in accordance with reality, because the total number of home helps is not equally divided over the six categories (Art et al. 1998).

Further research should focus on the causal relations between workload, pressure of work and capacity for coping, and on the significance of the variables included in the model.

\section{Acknowledgements}

This research was carried out at the initiative of the Ministry of Public Health, the Professional Association of Home Helps (STING), the Association of Management of Home Help Organizations (STRATEGO) and the Netherlands Institute of Primary Health Care (NIVEL). The study was financed by the National Centre of Nursing \& Caring (LCVV).

\section{References}

AbvaKabo (1994) Concept CAO-Thuiszorg met Salarisregelingen. AbvaKabo, Utrecht.

Algera J.A. (1981) Kenmerken Van Werk. Swets \& Zeitlinger, Lisse.

Algera J.A., van der Flier H. \& van der Kamp L.J.Th. (1986) Causal modelling of quality of work. In: The Psychology of Work and Organization (eds. G. Debus \& H.W. Schroiif). pp. 175-182. Elsevier Science Publishers, Amsterdam.

Arts S.E.J., Kerkstra A., Huijer Abu-Saad H. \& van der Zee J. (1998) A job profile of home helps in the Netherlands. for publication in Health and Social Care in the Community 6 (6), 397-406.

Arts S.E.J., Kersten J.W.E.T. \& Kerkstra A. (1997) Werken in de Gezinsverzorging. De Tijdstroom/ LCVV, Utrecht.

Bakker R.H.C., Knibbe J.J., Winkel A. \& te Friele R.D. (1995) Rugklachten van verzorgend en verplegend personeel van verzorgingshuizen. In: Rugklachten, Fysieke Belasting en Preventie Mogelijkheden in Verzorgingshuizen (ed. R.D. Friele). NIVEL, Utrecht.

Bergers G.P.A., Marcelissen F.H.G. \& de Wolff C.H. (1986) Vragenlijst Organisatie Stress-D Nijmegen. Vakgroep Arbeids; en Organisatiepsychologie Katholiek Universiteit Nijmegen, Nijmegen.

Boumans N.P.G. (1990) Het Werk Van Verpleegkundigen in Algemene Ziekenhuizen. Proefschrift; Rijksuniversiteit Limburg, Maastricht.

BVG (1994) BVG-Berichten, 1994. BVG, Zeist.

BVG (1996) BVG-Jaarverslag, 1995. BVG, Zeist.

Commissie Verzorging (1995) Zorg Voor Zorg. LCVV, Utrecht.

Dierendonck D. van (1997) Balancing give and take: an equity approach to burnout [dissertation]. University of Utrecht, Utrecht.

Dierendonck D. van, Groenewegan P.P., Sixma H. (1992) Opgebrand. Een inventariserend onderzoek naar gevoelens van motivatie en demotivatie bij huisartsen. NIVEL, Utrecht.

Engelen C.H.M.G. (1993) Arbeidsomstandigheden in de zorgsector. Tijdschrift Voor Verzorgenden 7, 198-204.

Hackman J.R. \& Oldham G.R. (1974) The Job Diagnostic Survey. Yale University, USA. 
Hackman J.R. \& Oldham G.R. (1975) Development of the Job Diagnostic Survey. Journal of Applied Psychology 60, 9-170.

Hackman J.R. \& Oldham G.R. (1976) Motivation through design of work: Test of a theory. Organizational Behaviour and Human Performance 16, 250-279.

Hackman J.R. \& Oldham G.R. (1980) Work Redesign. Wesley Publishing Company, Massachusetts.

van den Herik C., de Been M., Vulto M. (1995)`Alles draait om de cliënt'. De inhoud, het eigene en de kwaliteit van de arbeid van het uitvoerende werk in de gezinszorg. Rijksuniversiteit Leiden, Faculteit Sociale Wetenschappen, Vakgroep Vrouwenstudies, Leiden.

Hood J.N. \& Smith H.L. (1994) Quality of work life in home care. JONA 24 (1), 40-47.

Hornman M. (1994) Terwijl Je Afstoft Kom Je Heel Wat Tegen. Professionele Huishoudelijke Zorg: een Onmisbare Peiler Onder een Verantwoorde Thuiszorg. STING, Utrecht.

Hutten J.B.F. \& Kerkstra A. (1996) Home Care in Europe. Arena, Aldershot.

Jansen P.G.M., Kerkstra A., Huijer Abu-Saad H. \& van der Zee J. (1996) The effects of job characteristics and individual characteristics on job satisfaction and burnout in community nursing. International Journal of Nursing Studies 33 (4), 407-421.

Karasek R.A. (1979) Job demands, job decision latitude and mental strain implications for job redesign. Administrative Science Quarterly 24, 285-308.
Karasek R.A. \& Theorell T. (1990) Healthy Work: Stress, Productivity and the Reconstruction of Working Life. Basic Books, USA.

Meijman T.F. \& O'Hanlon J.F. (1984) Arbeidsbelasting, een inleidend overzicht van psychologische theorieën en meetmethoden. In: Handboek Arbeids; en Organisatiepsychologie (eds. P.J.D. Drenth, H. Thierry \& Ch.J. de Wolff). Van Loghum Slaterus, Deventer.

Norusis M.J./S.P.S.S. Inc. (1992) SPSS/PC+ tm Base System User's Guide, Version 5.0. SPSS Inc., Chicago.

Schaufeli W.B. \& van Dierendonck D. (1994) Burnout, een begrip gemeten. De Nederlandse versie van Maslach Burnout inventory (MBI-NL). Gedrag and Gezondheid 22, 153-171.

Scheurs P.J.G., van den Willige G., Tellegen B. \& Brosschot J.F. (1988) De Utrechtse Coping Lijst: UCL- Handleiding. Zwets \& Zeitlinger, Lisse.

Smulders P.G.W. \& Veerman T.J. (1990) Handboek Ziekteverzuim. Delwel, Den Haag.

van Tits M.\&. Groot W. (1991) Zorgen om kruiswerk en verzorging. Tijdschrift Voor Ziekenver-Pleging 101 (2), 56-59. van Tits M.\&. Vermeulen H. (1992) Ontwikkelingen op de arbeidsmarkt. Tijdschrift Voor Ziekenverpleging $102(3)$, 104-107.

Veerman T.J. (1989) Ziekteverzuim in de Gezinsverzorging. NIA, Amsterdam, Leiden.

van Veldhoven M.\&. Meijman T. (1994) Het Meten Van Psychosociale Arbeidsbelasting. NIA, Amsterdam. 
Copyright of Health \& Social Care in the Community is the property of Wiley-Blackwell and its content may not be copied or emailed to multiple sites or posted to a listserv without the copyright holder's express written permission. However, users may print, download, or email articles for individual use. 